\title{
A DIGNIDADE DA PESSOA HUMANA NO DIREITO CONSTITUCIONAL CONTEMPORÂNEO: A CONSTRUÇÃO DE UM CONCEITO JURÍDICO À LUZ DA JURISPRUDÊNCIA MUNDIAL
}

\author{
THE DIGNITY OF THE HUMAN PERSON IN CONTEMPORARY \\ CONSTITUTIONAL LAW: BUILDING A LEGAL CONCEPT IN THE LIGHT OF \\ WORLD JURISPRUDENCE
}

\section{2}

\section{João Pedro Minguete Goulart ${ }^{1}$}

BARROSO, Luís Roberto. A dignidade da pessoa humana no Direito Constitucional Contemporâneo: A construção de um conceito jurídico à luz da jurisprudência mundial. Tradução de Humberto Laport de Mello. 3ª ed. Belo Horizonte/MG: Fórum, 2014.

Barroso busca tornar o princípio da dignidade da pessoa humana um conceito mais substantivo no âmbito do discurso jurídico, no qual tem frequentemente funcionado como mero ornamento retórico e um cômodo recipiente para um conteúdo amorfo.

Para tal, o autor delimita três objetivos para seu texto: (I) demonstrar a importância que a dignidade humana assumiu na jurisprudência nacional e internacional, assim como no discurso transnacional; (II) precisar a natureza jurídica da dignidade da pessoa humana - direito fundamental, valor absoluto ou princípio jurídico? - e definir o seu conteúdo mínimo e (III) mostrar como a definição da natureza jurídica pode ser útil para estruturar o raciocínio jurídico nos casos moralmente controversos.

Nessa senda, pode-se dizer que sua ascensão como um conceito jurídico tem suas origens mais diretas no Direito Constitucional alemão. Assim, a Lei Fundamental de 1949 dispõe em seu Artigo I: "A dignidade humana deve ser inviolável. Respeitá-la e protegê-la será dever de toda a autoridade estatal". Por esta razão, o Tribunal Constitucional Federal Alemão reconheceu que a dignidade humana se situa no ápice do sistema constitucional, representando um valor supremo, um bem absoluto, à luz do qual cada um dos outros dispositivos deve ser interpretado.

Destarte, evidencia-se que a dignidade humana, consagrada ou não nos textos constitucionais ao redor do mundo, tem se tornado um instrumento argumentativo recorrente para Tribunais Constitucionais e Cortes Supremas de diferentes continentes.

No âmbito do Direito Internacional, esse valor fundamental tem sido inserido em uma

1 Cursando Programa de Pós-Graduação “Lato Sensu”(Especialização) em Direito e Processo Penal pela Universidade Estadual de Londrina (UEL). Bacharel em Direito pela Universidade Estadual de Londrina (UEL). E-mail: jpdrogoulart@gmail.com. 
grande quantidade de declarações e tratados. Assim, a Corte Europeia de Justiça (CEJ), tribunal mais elevado da União Europeia, tem utilizado o conceito de dignidade humana para fundamentar suas decisões em uma variada seleção de casos. Todavia, a CEJ reconheceu que a dignidade pode ter diferentes significados e alcances dentro do âmbito das jurisdições domésticas da União Europeia.

No discurso transnacional, constata-se que Tribunais de todo o mundo começaram a se engajar em um crescente diálogo constitucional, envolvendo citação mútua, conferências de intercâmbio acadêmico e organização de fóruns públicos. Barroso identifica dois fatores para esse fenômeno: (I) os países onde o Estado de Direito foi instaurado mais recentemente se espelham, com frequência, nas experiências democráticas mais sedimentadas e (II) há compartilhamento de experiências entre democracias maduras e tradicionais que, frequentemente, deparam-se com questões controversas semelhantes.

Ao tratar da natureza jurídica e do conteúdo mínimo da dignidade humana, Barroso apresenta a dignidade humana como um conceito multifacetado, argumentando que há razoável consenso de que se trata de um valor fundamental subjacente às democracias constitucionais de um modo geral, mesmo quando não expressamente previsto em suas constituições.

Barroso, no entanto, refuta a corrente doutrinária majoritária alemã que conceitua a dignidade humana como um valor absoluto, que prevalece em quaisquer circunstâncias. Menciona o Ministro que, embora seja razoável afirmar que a dignidade humana normalmente deve prevalecer, existem situações inevitáveis em que ela terá de ceder, ao menos parcialmente. Um exemplo evidente ocorre quando alguém é condenado à prisão após procedimento condizente com o devido processo legal: neste caso, um importante componente da dignidade, qual seja a liberdade, é sacrificado em benefício de outro valor relevante socialmente.

A dignidade humana é, portanto, um valor fundamental, mas que não deve ser tomado como absoluto. Assim, valores, seja eles políticos ou morais, permeiam o universo jurídico sob a forma de princípios e, desse modo, a melhor maneira de classificar a dignidade humana é como um princípio jurídico com status constitucional, e não como um direito autônomo. Como valor fundamental e como princípio constitucional, a dignidade humana funciona tanto como justificação moral quanto como fundamento jurídico-normativo dos direitos fundamentais.

Barroso sustenta que os princípios, em especial o da dignidade humana, tem dois propósitos essenciais: (I) funcionar como fonte de direitos (e deveres), incluindo aqueles não expressamente elencados nos diplomas normativos, e (II) auxiliar da orientação e interpretação das normas. Além disso, nos casos envolvendo lacunas no ordenamento jurídico, ambiguidades no direito, colisões entre direitos fundamentais, a dignidade humana pode funcionar como verdadeira bússola na busca da melhor solução.

Apesar de ser árdua a tarefa de esculpir um conceito transnacional unificado da dignidade humana, capaz de englobar todas as influências religiosas, históricas e políticas nos diferentes países, Barroso tenta estabelecer um conteúdo mínimo para o conceito, a fim de lhe conferir certo grau de objetividade. Destarte, na visão do autor, a dignidade humana identifica: (I) o valor intrínseco de todos os seres humanos; (II) a autonomia de cada indivíduo e (III) as limitações a ela 
impostas em razão de relevantes valores sociais e comunitários.

O valor intrínseco é, no plano filosófico, o elemento ontológico da dignidade humana, ligado à natureza do ser. Dele decorrem dois postulados: um antiutilitarista e outro antiautoritário. O primeiro se manifesta no imperativo categórico kantiano do homem como um fim em si mesmo, e não como um meio para a realização de metas coletivas; o segundo, na ideia de que é o Estado que existe para o indivíduo, e não o contrário. Desse modo, por ter o valor intrínseco de cada pessoa como conteúdo essencial que a dignidade humana é, em primeiro plano, um valor objetivo, independendo de qualquer evento ou experiência e não podendo ser cedido ou perdido. No plano jurídico, o valor intrínseco está na origem um conjunto de direitos fundamentais, como os direitos à vida, à igualdade e à integridade física e psíquica.

A autonomia, por sua vez, é o elemento ético. É o fundamento do livre arbítrio dos indivíduos, que lhes permite buscar, de sua própria maneira, o ideal de viver bem e de ter uma vida boa. Subdivide-se em 3 categorias: autonomia privada, autonomia pública e mínimo existencial. A primeira delas é o conceito-chave por trás das liberdades individuais. A autonomia pública está relacionada às liberdades republicanas, associadas à cidadania e à participação na vida política. Finalmente, quanto ao mínimo existencial, para que os indivíduos sejam livres, iguais e capazes de exercer uma cidadania responsável, estes necessitam estar além dos limiares mínimos de bemestar, sob pena de a autonomia se tornar mera ficção, e a verdadeira dignidade não existir. Isso exige o acesso a algumas prestações essenciais, assim como a satisfação de necessidades elementares.

O terceiro e último elemento representa o aspecto social, identificando duas diferentes forças exógenas que agem sobre o indivíduo: (I) os compromissos, valores e "crenças compartilhadas" de um grupo social e (II) as normas impostas pelo Estado. A dignidade como valor comunitário enfatiza, portanto, o papel do Estado e da comunidade no estabelecimento de metas coletivas e restrições sobre direitos e liberdades individuais em nome da coletividade. Assim, o valor comunitário, como restrição sobre a autonomia pessoal, busca a realização de três objetivos: (I) a proteção dos direitos e da dignidade de terceiros; (II) a proteção dos direitos e da dignidade do próprio indivíduo e a proteção de valores sociais compartilhados.

Assim, compilando constatações do discurso transnacional, fica clara a tentativa do autor de estabelecer critérios mais objetivos para a aferição do conceito e do conteúdo mínimo do princípio com status constitucional da dignidade humana, a fim de que este valor fundamental sirva como base de orientação e interpretação na solução dos casos moralmente controvertidos. 